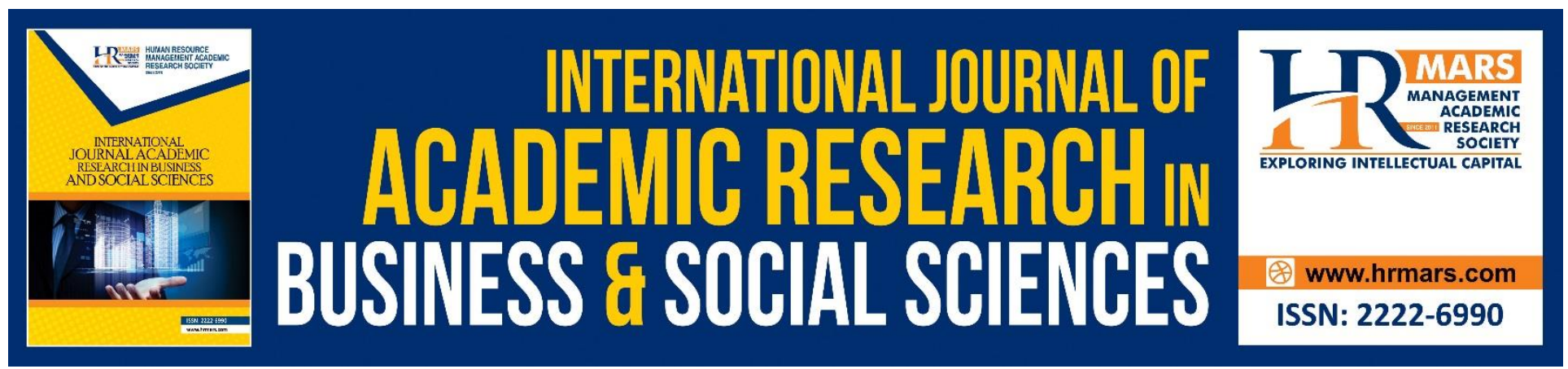

\title{
A Distribution of Zakah to Al-Riqab: Critical Analysis of Fatwa and Views of Mufassir
}

Nur Anisah Nordin \& Wan Mohd Khairul Firdaus Wan Khairuldin

To Link this Article: http://dx.doi.org/10.6007/IJARBSS/v8-i11/4973

DOI: $10.6007 /$ IJARBSS/v8-i11/4973

Received: 24 Sept 2018, Revised: 21 Oct 2018, Accepted: 16 Nov 2018

Published Online: 28 Nov 2018

In-Text Citation: (Nordin \& Khairuldin, 2018)

To Cite this Article: Nordin, N. A., \& Khairuldin, W. M. K. F. W. (2018). A Distribution of Zakah to Al-Riqab: Critical Analysis of Fatwa and Views of Mufassir. International Journal of Academic Research in Business and Social Sciences, 8(11), 958-964.

Copyright: (C) 2018 The Author(s)

Published by Human Resource Management Academic Research Society (www.hrmars.com)

This article is published under the Creative Commons Attribution (CC BY 4.0) license. Anyone may reproduce, distribute, translate and create derivative works of this article (for both commercial and non-commercial purposes), subject to full attribution to the original publication and authors. The full terms of this license may be seen

at: http://creativecommons.org/licences/by/4.0/legalcode

Vol. 8, No. 11, 2018, Pg. 958 - 964

Full Terms \& Conditions of access and use can be found at http://hrmars.com/index.php/pages/detail/publication-ethics 


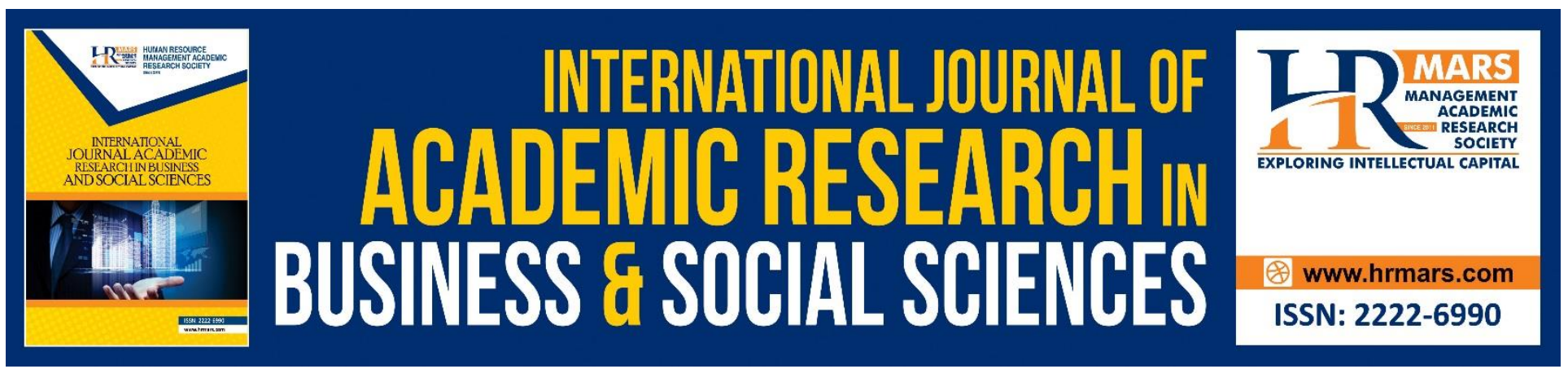

\title{
A Distribution of Zakah to Al-Riqab: Critical Analysis of Fatwa and Views of Mufassir
}

\author{
Nur Anisah Nordin \& Wan Mohd Khairul Firdaus Wan Khairuldin \\ Faculty of Islamic Contemporary Studies, Universiti Sultan Zainal Abidin, Terengganu. Malaysia \\ Email:wanfirdaus@unisza.edu.my
}

\begin{abstract}
This paper attempts to discuss the distribution based on the concept of asnaf al-Riqab. This paper is also performed to see the definition of al-Riqab based on the interpretation of contemporary or classical mufassir. This is because asnaf $a l-R i q a b$ is among the asnaf which often became the debate of the scholars because of the ambiguity of his position. There are groups who distribute and there are also who do not distribute zakat to this asnaf. The purpose of the paperwork is divided into two. First, identify the concept of distribution of zakah to al-Riqab. Second, analyzing the views of classical and contemporary mufassir in interpreting the term al-Riqab based on verse 60, surah al-Taubah. The data in this study were collected through a document study and then analyzed using content analysis methods. The findings show that contemporary interpretations are widely used in zakat institutions in Malaysia rather than classical interpretations. Although slavery is virtually absent from the classical interpretation, contemporary mufassir views expand the distribution according to current circumstances. Classical and contemporary distribution will be a guide to distributing zakah al-Riqab.
\end{abstract}

Keywords: Fatwa, Distribution, Al-Riqab, Mufassir.

\section{INTRODUCTION}

In surah al-Taubah, verse 60, Allah SWT placed the rank of asnaf al-Riqab in fifth position. This order is based on asnaf entitled to receive zakat starting with faqir, poor, amil, mualaf, al-Riqab, alGharimin, fi sabilillah and ibn al-sabil. According to IbnKathir (1999: 150/2), the distribution of zakat should be given to eight groups as set out in surah al-Taubah, verse 60 .

The Arabs in the jahiliyyah era made the slave a merchandise or exchange for a dowry or gift for their offspring ( Nasution, 2015: 97). However, the presence of Islam has wiped out the system of slavery created during the jahiliyyah period. According to Sabiq (2003: 132), al-Riqab, if viewed in 
INTERNATIONAL JOURNAL OF ACADEMIC RESEARCH IN BUSINESS AND SOCIAL SCIENCES

Vol. 8, No. 11, Nov, 2018, E-ISSN: 2222-6990 C 2018 HRMARS

terms of general definition, means 'makatab' which is the servant who has been redeemed or purchased to be freed from his master gradually.

According to Ridha (1999: 598), al-Riqab is one of the groups who want to escape from slavery or occupation and fight for independence. Furthermore, al-Qaradawi (2011: 416) argues that al-Riqab is a bonded servant or bondage that binds one's liberty. Based on observations, there are differences in the definition of al-Riqab among scholars'. However, this distinction is not significant, which is still meaningful to slave or liberation.

Thus, the issue of distribution of zakat to al-Riqab is nowadays. This is due to the inconsistency of zakat institutions in Malaysia. Therefore, a systematic study should be carried out to see the definition of asnaf al-Riqab based on the views of the mufassir. As such, this paper attempts at least to explain in general the distribution of zakat to Bibliography based on the critical analysis of the views of the taxpayer based on their definitions.

\section{METHODOLOGY}

This study uses a method of documentation to obtain a clear overview of asnaf al-Riqab and the method of distribution of zakat to al-Riqab based on the critical analysis of the views of the mufassir. To obtain information related to the concept of al-Riqab, the definition of asnaf al-Riqab is taken on the basis of classical and contemporary mufassir views and interpret the 'fi' and 'lam' word based on the surah al-Taubah to be examined.

According to Jasmi (2012), this document analysis method is used to obtain clear information in understanding the concepts, issues and problems of a phenomenon occurring. Subsequently, the result of the data collection will be analyzed using the content analysis method. Content analysis is used to examine and explain the interpretation contained in the document. According to Yusof (2004: 34), analyzing content is a research technique by making systematic and objective conclusions through documented data. While Marican (2005: 170) and Lebar (2009: 146) define content analysis as an explanation systematically researching textual expressions. This corresponds to the data collected from the related documents of asnaf al-Riqab which analyzed the views of classical and contemporary mufassir in defining al-Riqab. Among the works of the mufassirs used are Tafsir of alQurtubi, Tafsir of Ibn kathir, the Tafsir of al-Tabari and the interpretation of al-Razi which represents the classic main interpretation used first. Meanwhile, tafsir al-Azhar and contemporary tafsir alManar are widely used today's interpretation. 
INTERNATIONAL JOURNAL OF ACADEMIC RESEARCH IN BUSINESS AND SOCIAL SCIENCES

Vol. 8, No. 11, Nov, 2018, E-ISSN: 2222-6990 @ 2018 HRMARS

\section{FINDINGS STUDY}

This study divides the discussion into al-Riqab concept based on the mufassir.

The concept of al-Riqab is based on the mufassir

a) Definition of $a l-R i q a b$

The word al-Riqab is plural, his sole name is 'raqabah'. According to the etymological point of view the neck, the end of the head or body part. While the terminology 'raqabah' means the slave possessed (al-Razi, 1999: 86; al-Zamakhsyari, 1986: 283). Based on the study of researchers there is no specific interpretation of the definition of al-Riqab from both sides of the language or terminology.

\section{The definition of asnaf al-Riqab based on classic and contemporary mufasir experts}

There are some views expressed by classical mufassirs. This paper explains the views of Ibn Kathir, alQurtubi, al-Tabari and al-Razi. According to al-Qurtubi (1946: 182 \& 183), slaves freed from the colony are slaves 'mukatab', not real slaves. The servant of 'mukatab' means the servant who made an agreement with his master to pay a gradual release as a liberation from slavery. Therefore, the zakat or zakat payer may use zakat for asnaf al-Riqab to liberate 'mukatab' slaves from slavery.

IbnKathir (1999: 168), as quoted by Ibn Abbas and Hasan, stated that the slave deserved the share of zakat. In other words, the slave in general from the perspective of the term means, is not the slave of the 'mukatab' alone, even the whole. Zakah property can be freed to free slave.

Besides, al-Tabari (2011: 186) states that slaves are individuals who want to redeem themselves from the slavery of their master. Allah SWT makes zakat as a mandatory obligation to withdraw from the property. This is because liberating slaves from slavery benefits from liberating from slavery and restoring human nature born with freedom.

Furthermore, al-Razi (1999) defines asnaf al-Riqab as a Muslim slave who pays gradually to his master to redeem himself. This is because the property they own is not enough to live despite hard work. Therefore, the distribution of zakat is granted or purchased from his master to free himself from the bondage. This view is based on opinion in madhhab Shafi'i .

In conclusion, the difference views of the classic mufassir on the definition that shows the summary of classical scholars' ijtihad related to the definition of al-Riqab. Al-Qurtubi (1946: 182-183), al-Tabari (2011: 186) and al-Razi (1999), ijtihad al-Riqab means the 'mukatab' slave or slave servant. While the opinion of IbnKathir (1999: 168), the definition of al-Riqab began to be expanded with not merely slaves, even slaves. But the definition of al-Riqab which is cited in the view of the mufassir based on slaves, because in those times, slaves had not been completely abolished.

In addition to classic views, this paper also explains the definition of al-Riqab through contemporary interpretations. According to HAMKA (1984), religious councils are still using a system of slavery, in which the share of zakat is allocated to 'mukatab' slaves. This is because part of the property is allocated to buy slaves to liberate slaves. As an example of the master to the servant said, if you can pay my losses then you are released. The slave can claim his freedom at the zakat institution to request the release of his master.

According to Ridha (1999: 598), al-Riqab is one of those nations who want to escape from slavery, colonization and fight for independence. This is because the shackles of the colonization are more harmful to the humanitarian value that involves the slavery of the nation that influences thought, possessions and government. 
INTERNATIONAL JOURNAL OF ACADEMIC RESEARCH IN BUSINESS AND SOCIAL SCIENCES Vol. 8, No. 11, Nov, 2018, E-ISSN: 2222-6990 @ 2018 HRMARS

In conclusion, the views of contemporary mufassir also have differences from the definition described above. HAMKA's view (1984), explains the division of zakat allocated to the servant of 'mukatab' by using al-Riqab zakat division at the religious ceremony. While Rasyid Ridha's view extends the definition of al-Riqab which states that despite the general angle of the corner servant does not exist, modern slavery is more dangerous to humans. The slavery involving the group is shackled from the point of thought, wealth, freedom and power.

Table 1: Interpretation of al-Riqab according to classical and contemporary mufasir.

\begin{tabular}{|l|l|l|l|}
\hline No & Classic Tafsir & $\begin{array}{l}\text { Contemporary } \\
\text { Tafsir }\end{array}$ & Distributed to al-Riqab \\
\hline 1 & Tafsir al-Qurtubi & & Slave 'mukatab'. \\
\hline 2 & Tafsir Ibn Kathir & & $\begin{array}{l}\text { Not counting slaves 'mukatab' or ordinary } \\
\text { slaves, but altogether }\end{array}$ \\
\hline 3 & Tafsir al-Tabari & & Slave 'mukatab'. \\
\hline 4 & Tafsir al-Razi & & Slave 'mukatab'. \\
\hline 6 & & Tafsir al-Azhar & Slave 'mukatab'. \\
\hline 6 & Tafsir al-Manar & $\begin{array}{l}\text { Slaves bonded out of the colonies involving } \\
\text { slavery of groups influencing thoughts, } \\
\text { possessions and governments. }\end{array}$ \\
\hline
\end{tabular}

(Source: The Books of the Mufassir).

The results of the books of mufassir show the interpretation made by al-Qurtubi (1946: 182 \& 183), al-Tabari, al-Razi (1999) and HAMKA (1984), giving to the slaves 'mukatab' only. Ibn Kathir said slaves, while the whole of Ridha (1999: 598), expanding by looking at the shackles of the bondage colonization instead the bondage from slavery.

In conclusion: al-Riqab according to the views of the classical mufassir is more using the liberating approach of slaves than the jahiliyyah system of slavery. The system demands a servant who wants to be released to pay some money to free them. Therefore, because Islam sees a need to abolish this slavery system. Meanwhile, the views of contemporary mufassir use the approach to expanding alRiqab. This is because the servants of today do not exist from the general point of view; however, modern-day slavery is more dangerous to humans because of the slavery of people, races or groups involving thought, wealth, freedom and power.

\section{ANALYSIS AND DISCUSSION.}

Based on the discussion on asnaf al-Riqab, the mufassir divided into several categories. The categories are divided into three namely slave in general, servant 'mukatab' and slave in fetters by thought, wealth, freedom and power. 
INTERNATIONAL JOURNAL OF ACADEMIC RESEARCH IN BUSINESS AND SOCIAL SCIENCES Vol. 8, No. 11, Nov, 2018, E-ISSN: 2222-6990 C 2018 HRMARS

The first category, according to IbnKathir (1999: 168), states the definition of slaves in general. Slaves are not just slaves of the 'mukatab' but entirely. Slavery is generally more beneficial to the community or the nation.

Apart from general interpretation of slaves, slave for the second category is slaves 'mukatab'. This is because the servant of 'mukatab' has an agreement with his master to pay off the debt gradually. The allocation of zakat al-Riqab can escape the slavery. The views of the mufassir are based on alQurtubi (1946: 182-183), al-Tabari (2011: 186), al-Razi (1999) and HAMKA (1984).

While the third category, Ridha (1999: 598), stated that slaves should be freed from the shackles of thought, wealth, freedom and power from the ruler. This is more dangerous and harmful to the group. Freedom from slavery can lift the rank and get rid of humiliation.

In conclusion: according to the views of the classical and contemporary mufassir, al-Riqab is based of the slave, either a general servant or an 'mukatab' servant. This is because the Islamic revival eliminates the system of slavery made during the days of ignorance. Yet a slight difference made by Ridha (1999: 598) states slavery freedom from the shackles of thought, wealth, freedom and power from the ruler.

But Ridha (1999: 598) views are in line with Shaltut (n.d) views stating that this group should be helped and more dangerous than actual slavery. This is because the slavery is based on the shackles of slavery in the form of thought, wealth, freedom and power of government. This slavery demonstrates compassion and responsibility for liberating modern slavery.

IbnKathir's views (1999: 168), al-Qurtubi (1946: 182-183), al-Tabari (2011: 186) and al-Razi (1999) state that the slave is bound by debt including of the slaves in general or mukcom slaves. This slavery should be assisted by the use of zakat al-Riqab because bondage bonded by debt can harm the slave who has no property to liberate himself from slavery through their owners.

Hence, the views of the mufassir still maintain the interpretation of al-Riqab to the servant. While Ridha (1999: 598) states that the slave does not exist in the present day. Hence the interpretation is intended for them, referring to the group bound by the thinking, wealth, freedom and power of the government. This is because this slavery is more dangerous than actual slavery.

\section{CONCLUSION}

This paper attempts to refine the discussion on the study of the position and distribution of zakat to al-Riqab: a critical analysis of the views of the mufassir. This paper concludes with some conclusions on this study:

1. The difference in the definition of classic mufassir based on the jahiliyyah bondage system. While the definition of contemporary mufassir is aimed at slavery from a modern angle involving slavery of form of thought, wealth, freedom and power. 
INTERNATIONAL JOURNAL OF ACADEMIC RESEARCH IN BUSINESS AND SOCIAL SCIENCES

Vol. 8, No. 11, Nov, 2018, E-ISSN: 2222-6990 @ 2018 HRMARS

2. Asnaf al-Riqab requires a broader definition. This is because asnaf al-Riqab is a general maslahah. Al-Riqab should be studied in various angles so that asnaf al-Riqab can be given to people who are truly entitled.

\section{ACKNOWLEDGEMENT}

This project was funded by the Special Research Grant Scheme (SRGS) from UniSZA (UniSZA/2017/SRGS/07). We would like to thank UniSZA for the financing provided.

\section{References}

IbnKathir, I. (1999). Tafsir al-Quran al-Azim. Beirut-Lubnan: Dar al-Tiba'ah wa al-Nasr wa al-Tauzi'. Nasution, A.S. (2015). Perbudakan dalam Hukum Islam. Makalah yang dibentangkan di Ahkam Vol 1. XV, No.1, Januari 2015. hlm. 95-102

Salim, S. (2003). Shahih Fighis Sunnah wa Adillatuhu fi Taudhih Madzahib al-A'immah. KaherahMesir: Maktabah Taufi-qiyyah.

Al-Qaradawi, Y. (2011). Fiqh al-Zakat. Beirut: Muassasah al-Risalah al-Nasyirun.

Lebar, O. (2009). Penyelidikan Kualitatif: Pengenalan kepada Teori \& Metodologi. Tanjung Malim: Penerbit Universiti Pendidikan Sultan Idris (UPSI).

Yusof, R. (2004). Penyelidikan Sains Sosial. Kuala Lumpur: PTS Publications \& Distributors.

Marican, S. (2005). Kaedah Penyelidikan Sains Sosial. Petaling Jaya: Pearson Hall.

Jasmi, K.A. (2012). Metodologi Pengumpulan Data dalam Penyelidikan Kualitatif. JohorBharu: Universiti Teknologi Malaysia.

Khairuldin, W.M.K.F.W. (2010), Metode Fatwa Sheikh 'Ali Jumaa'ah dalam Kitab al-Kalim al-TayyibFatawa 'Asriyyah. Unpublished Master Thesis. University of Malaya.

Khairuldin, W.M.K.F.W. (2016), Konsep Fatwa dalam Islam. Kuala Terengganu: Penerbit Universiti Sultan Zainal Abidin.

Khairuldin, W. M. K. F. W., Embong, A. H., Anas, W.N.I.W.N., Mohd, H. \& Ismail, D. (2018). The Application of Technology in the Dissemination of Fatwas: A Study on Religious Institutions in Malaysia, International Journal of Civil Engineering and Technology, 9(7), 2018, pp. 15901596.

Al-Razi, F. (1999). Al-Khabir/ Mafatihul Ghoib. Beirut-Lubnan: Dar Ihyan al-Tirasa al-Arabi HAMKA. (1984). Tafsir Al-Azhar. Singapura: Pustaka Nasional PTE LTD.

Al-Qurtubi, M.A. (1946). Al-Jami' Li Ahkam Al-Quran Wa Al-Mubayyin Li Ma Tadhammanahu Min AsSunnah Wa Aiy Al-Furqan. Kaherah-Mesir: Dar al-Kitab al-Masriah.

Al-Tabari, I.J. (2001). Jami' al-Bayan fi Ta'wil al-Quran. Beirut: Dar al-Fikr li al-Tiba'ah wa al-Nasr wa al-Tauzi'

Al-Zamakhshari, M.U, (1986). Al-Kasyaf 'An-Haqaa'iq Ghawamidh at-Tanziil. Beirut-Lubnan: Dar alKitab al-arabi.

Shaltut, M. (tn.d). Al-Fatawa. Kaherah: Dar al-Qalam.

Ridha, M.R. (1999). Tafsir Al-Manar. Kaherah-Mesir: Dar al-Kutub al-'Ilmiyyah 